Revista de la red interuniversitaria de estudios sobre las literaturas rioplatenses contemporáneas en Francia

16 | 2017

Esnobismos

\title{
Del gusto y sus disputas
}

\section{Mariana Dimópulos}

Electronic version
URL: http://journals.openedition.org/lirico/3735

DOI: $10.4000 /$ lirico.3735

ISSN: 2262-8339

\section{Publisher}

Réseau interuniversitaire d'étude des littératures contemporaines du Río de la Plata

\section{Electronic reference}

Mariana Dimópulos, « Del gusto y sus disputas », Cuadernos LIRICO [En línea], 16 | 2017, Puesto en línea el 06 octubre 2017, consultado el 21 abril 2019. URL : http://journals.openedition.org/lirico/3735 ; DOI : 10.4000/lirico.3735

This text was automatically generated on 21 April 2019

\section{(c) (i) (9)}

Cuadernos LIRICO está distribuido bajo una Licencia Creative Commons Atribución-NoComercialSinDerivar 4.0 Internacional. 


\title{
Del gusto y sus disputas
}

\author{
Mariana Dimópulos
}

1 El término gusto compartió tempranamente al menos dos ámbitos semánticos; el originario del latín y de la esfera de la degustación culinaria, y luego el de las preferencias personales sobre diversos objetos y prácticas, incluido el juicio sobre lo bello. Fue durante el siglo XVIII que se generalizó como criterio aplicado a las artes, aunque según el diccionario de Corominas la reina Isabel ya lo usaba como "sentido estético justo". Este segundo uso trae consigo una tensión entre objetividad y arbitrariedad. Sobre este punto de inconsistencia entre preferencia personal como acto arbitrario y pretensión de objetividad como criterio común fue que se detuvo un filósofo que haría del gusto una herramienta analítica. Kant buscó en su Crítica del juicio fundamentar y al menos por un momento anular esta diferencia. Se discutía entonces si el gusto se limitaba a ser algo por completo idiosincrático de la persona, o si había en ello algo de universal, aunque como bien recordaba Kant, esa universalidad no podía basarse en un concepto del entendimiento, puesto que el juicio estético no representaba conocimiento alguno. El viejo adagio De gustibus non est disputandum podía interpretarse entonces de dos maneras : cada uno a su gusto, o bien : el verdadero gusto, el buen gusto, no debe renunciar a su pretensión de ser universal, y por esto mismo tampoco podrá ser objeto de disputa, o al menos no de discusión.

2 Durante el siglo XVII francés, este carácter colectivo del (buen) gusto había comenzado a ser un modo de identificar al honnête homme; cobró desde entonces, por ende, una dimensión socialmente normativa. Por este desvío, podemos conjeturar, terminó regresando desde sus orígenes latinos nuevamente a la esfera culinaria. Erasmo ya había redactado en el siglo XVI De la urbanidad en las maneras de los niños, en el que dedicaba una parte a los modales en la mesa con intención normativa y civilizatoria. Desde allí, es posible tender un arco hasta las reflexiones de Brillat-Savarin sobre el gusto, donde coinciden el degustar, el juicio y el comportamiento adecuado del hombre civil. No sorprende entonces que la esfera de la comida y de la distinción hayan acabado confluyendo.

3 Con el avance del pensamiento social, por un lado, y por el otro con el lento auge de la cultura de masas, que fue invadiendo progresivamente las mentes (burguesas) del siglo 
XIX, la comida se convirtió en una práctica cultural especialmente visible, y por ende tanto objeto de normas como herramienta de distinción. La sociología, que se detuvo en la descripción de este acto de distinción por clases y descubrió en el gusto un sistema de esquemas clasificatorios, volvió a instalar la querella implícita en el adagio medieval, dado que por principio tiende a negar la autonomía individual en la decisión del gusto. Esta sociología ve en el gusto una suerte de falsa conciencia que se cree libre al decidir si come este plato o si gusta de tal obra de arte. En verdad, es la distinción la que está operando en las supuestas decisiones, ante todo de la clase burguesa con respecto a las otras. El gusto no es más que función de un mercado de bienes culturales, mercado que tanto genera gusto para colocar sus productos, como crea productos que respondan al gusto existente. De este gregarismo del hombre social no es posible salir. Se regresa así a una suerte de generalización del gusto, a pesar de su fama de escurridizo y personal. La dificultad planteada por Kant vendría entonces a resolverse a medias, en universales fragmentados. Es decir, se ha invertido la evidencia primera : todo lo personal en el gusto se ha vuelto un espejismo, un acto colectivo. Pero al menos dos tipos sociales parecen haberse revelado ante tal determinación : el dandy y el esnob.

4 Ante el temor a la masificación, el siglo XIX fue pasto adecuado para engendrarlos y desplegarlos al mismo tiempo como personajes de la literatura. El primero encarna, según la diferencia aceptada habitualmente, a aquel que busca la originalidad y se alimenta para ello de su talento ; el otro, con mayor espíritu gregario, se propone más bien distanciarse simplemente de su propia clase, apropiándose así de los gustos de aquel sector social que admira; lo pretendidamente nuevo que tiene para aportar es más bien producto de un mimetismo. En su individualidad, ambos parecen encarnar la contracara de esa igualdad que el siglo de las revoluciones había proclamado una y otra vez. Esta práctica de la distinción es reconocible también en la comida; cabe recordar el camino invertido del alimento retratado en À Rebours de Huysmans. O los esnobs que recorren los jardines de Gatsby en sus banquetes nocturnos al aire libre, con sus salchichas en hojaldre y las ensaladas dispuestas formando dibujos.

5 ¿Es posible que ambos tipos sociales caigan necesariamente, uno por la ilusión de la novedad única y el otro por la mímesis de la pertenencia, en la trampa de un individualismo inexistente?

6 El gusto es un destino, dice Bourdieu en su libro dedicado a la distinción, y queriéndolo o sin querer parece parafrasear la antigua sentencia griega sobre el carácter del hombre, una variación del problema de la determinación o el libre albedrío. Tampoco los alimentos, que son al menos etimológicamente el ámbito originario del gusto, se sustraen de esta condena, no solo por lo cultural - no hay sabores preferidos propiamente, todos son adquiridos- sino por ser parte del lifestyle que construye distinción en el mercado de circulación simbólica de los bienes culturales. En resumen : quien crea que decide algo verdaderamente por gusto propio, se equivoca.

7 Pero la filosofía, a diferencia de la sociología, no renuncia fácilmente a la idea de una autonomía, como tampoco a un universal posible. Esta pretensión llegó también al ámbito culinario, una vez más por vía de las maneras de mesa, aunque ya no por la apelación a las buenas costumbres y al espíritu civilizatorio. A principios del siglo XX un autor como Georg Simmel ensayó una mínima solución para esta famosa antinomia de lo universal y lo particular en el gusto, usando el rodeo de la mesa. En su "Sociología de la comida", afirmaba en 1910 : 
Respecto a la fuente de la que simplemente se tomaba la comida en las épocas primitivas, el plato es una figura individualista. Nos señala que esa porción de comida ha sido aislada exclusivamente para esa persona.

La forma redonda del plato lo marca ; la línea del círculo es el dibujo más cerrado, su contenido es el más concentrado en sí mismo, mientras que la fuente de comida disponible para todos es rectangular u oval, es decir, está menos celosamente cerrada sobre sí. El plato simboliza ese orden que da a la necesidad del individuo aquello que le corresponde como parte de un todo subdividido en porciones, ese orden que, a su vez, no le permite ir más allá de este límite. Sin embargo, el plato también anula y sobrepasa este individualismo simbólico en una comunidad más perfecta y más formalizada : los platos de una mesa deben ser idénticos entre sí, no toleran que haya alguna individualidad que los diferencie; utilizar platos o vasos diversos para diversas personas sería absolutamente desagradable y absurdo. ${ }^{1}$

8 Así, acaso el plato resuelva la antinomia de lo universal y lo particular encerrada en el gusto, dentro y fuera de las preferencias culinarias. En su individualidad mediada, es decir en su secreto gregarismo, también el esnob representa en cierto modo la unión de lo que parecía imposible: aquello propio que en verdad es de otros, y que al mismo tiempo debería distinguirlo de muchos otros más. Eso hace la validez y, al mismo tiempo, la invalidez de la pretensión en la que vive este personaje. No es fácil su tarea; se ha propuesto encarnar una muy antigua dificultad.

\section{NOTES}

1. G. Simmel, "Soziologie der Mahlzeit". Berlín: Der Zeitgeist, Anexo al Berliner Tageblatt, $\mathrm{n}^{\circ}$ 41, 10 de octubre de 1910, pp. 1-2. [Número conmemorativo de los cien años de la Universidad de Berlín]

\section{AUTHOR}

\section{MARIANA DIMÓPULOS}

Escritora y traductora, compiló junto con Mariano García el libro Escritos sobre la mesa. Literatura y comida, Buenos Aires, Adriana Hidalgo, 2014 